\title{
UGT2B7 Gene
}

National Cancer Institute

\section{Source}

National Cancer Institute. UGT2B7 Gene. NCI Thesaurus. Code C105575.

This gene plays a role in estrogen metabolism. 